\title{
FROM ASSESSMENT OF ORGANIZATION'S FINANCIAL STANDING TO INTEGRATED METHODOLOGY FOR ANALYSIS OF SUSTAINABLE DEVELOPMENT
}

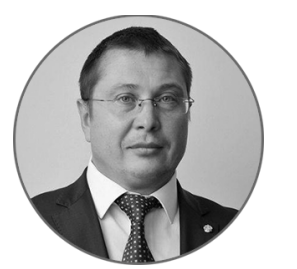

Dmitrii A. ENDOVITSKII

Voronezh State University, Voronezh, Russian Federation

eda@vsu.ru

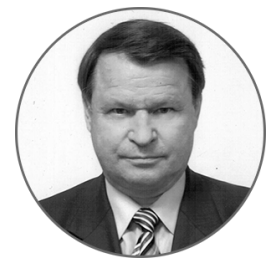

Nikolai P. LYUBUSHIN

Voronezh State University, Voronezh, Russian Federation lubushinnp@mail.ru

Corresponding author

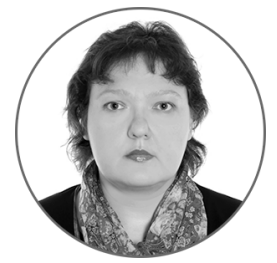

Nadezhda E. BABICHEVA

Voronezh State University, Voronezh, Russian Federation sigaeva@mail.ru

\section{Ol'ga M. KUPRYUSHINA}

Voronezh State University, Voronezh, Russian Federation

olgakupryushina@umc.vsu.ru

\section{Article history:}

Received 16 November 2016 Received in revised form

22 November 2016

Accepted 1 December 2016

Translated 25 May 2017

Available online 15 June 2017

JEL classification: 012, 001

\begin{abstract}
Importance The issue of sustainable development and sustainable growth of social product has been discussed by the international professional community since the second half of the 20th century. Nowadays, there is a need to develop key indicators characterizing both financial standing and sustainable development of organizations, and a methodology for their assessment.

Objectives The aim of the study is to review the problems related to the assessment of financial condition and analysis of sustainable development of organizations.

Methods The study draws upon general scientific principles and research methods, namely, analysis and synthesis, induction and deduction, grouping, comparison, abstraction, generalization, analogy, and modeling.

Results Sustainable development can be viewed as a process and as a state. As a process, the sustainable development of the organization has a time period, during which its characteristics change. The principal characteristic is a relative share of intensive factors in the revenue for the considered type of resources. It served as a classification criterion for evaluation of processes according to the golden ratio principle. We identify absolute, stable, unstable, and crisis types of sustainable development.

Conclusions and Relevance The analysis of organizations' operations is impeded by the lack of legal framework
\end{abstract}


D.A. Endovitskii et al./ Digest Finance, 2017, volume 22, issue 2, pages 123-143

Keywords: resource, intensive factor, financial standing, sustainable development, integrated reporting and available averaged values of indicators characterizing the financial condition by type of economic activity. It is important to develop analytical procedures that measure all types of capital of integrated reporting, the interactions between them, and the value of the entire business.

๑) Publishing house FINANCE and CREDIT, 2016

The editor-in-charge of this article was Irina M. Komarova

Authorized translation by Irina M. Komarova

The globalization of economies around the world increases the relevance of key indicators of corporate competitiveness. Economic agents (organizations, companies) strive to maximize their profit, business capitalization, and ensure sustainable development.

As set forth in Article 50 of the RF Civil Code, commercial entities see deriving profit as the chief goal of their activity in the market economy. The goal explains why so much attention is paid to the evaluation of financial results of any company, which are assessed on the basis of principles of the dynamic balance sheet theory. As per the theory, income and related expenses can be estimated for a certain period, thus measuring the financial result for the period in question. Income and expenses depend on multiple factors and require to assess many indicators of the entity's financial standing. For instance, as promulgated by the Central Bank of the Russian Federation in subparagraph 3.2.2 of Resolution of March 26, 2004 № 254- $\Pi^{1}$, credit institutions at their own discretion determine the list of indicators that shall be used to analyze the financial position of a borrower, and set up rules for their assessment. Most methods for analyzing the entities' financial position include groups of indicators reflecting solvency, creditworthiness (the ability to repay debts, and liquidity), financial sustainability.

Evaluation of Corporate Solvency. Financial position evaluation is indispensable without the concept of corporate insolvency. Legislative and regulatory documents and insolvency evaluation criteria became the focal point in the 1990s, when most entities modified their business and legal structure. Law-makers released three editions of the law on insolvency in 1992, 1998 and $2002^{2}$. The law is constantly amended,

\footnotetext{
${ }^{1}$ Regulation of the Central Bank of the Russian Federation On Rules for Credit Institutions to Make Provisions for Possible Losses from Loans and Identical Borrowings of March 26, 2004 № 254-П (with amendments as of September 1, 2015).

${ }^{2}$ RF Federal Law On Insolvency (Bankruptcy) of Enterprises of November 19, 1992 № 3929-I; RF Federal Law On Insolvency (Bankruptcy) of January 8, 1998 № 6-Ф3; RF Federal Law On Insolvency (Bankruptcy) of October 26, 2002 № 127-Ф3.
}

with the recent amendments being made in September 2016.

As seen worldwide, insolvency is evaluated on the basis of two criteria only, i.e. insufficiency of property to cover the debt (inability to repay) and insolvency, i.e. the debtor's inability to pay. In 1890, G.F. Shershenevich, renowned Russian scholar, studied very profoundly and insightfully whether the above criteria could be used, and preferred the system that was based on the debtor's inability to pay [1, p. 77].

Nevertheless, the RF Law On Insolvency (Bankruptcy) (1992) stipulated the inability to pay. That is the entity shall be deemed insolvent only if total payables exceed the property value. As the law enforcement showed, entities managed to stay formally solvent in their financial statements for a long time by adjusting their accounts receivable and payable and remeasuring their assets. For the law enforcement purposes, law-makers adopted Resolution of the RF Government On Some Measures for Enforcement of the Legislation on Corporate Insolvency (Bankruptcy) of May 20, 1994 № 498, which provided for two financial ratios:

- current ratio $k_{\text {cur.lqt, }}$ statutory value of $k_{\text {cur.lqt }}>2$;

- working capital-to-current assets ratio $k_{\text {fin.sust, }}$ statutory value of $k_{\text {fin.sust }}>0.1$.

Fig. 1 shows trends in the current ratio, and working capital-to-current assets ratio and equity-to-asset ratio for the period within 1995-2015. Adhering to the above criteria, the Russian economy can be qualified as debt-laden, since the working capital-to-current assets ratio remains negative starting from 1996. The ratios have not approximated statutory values for a long time, thus indicating the unrealistic nature of the statutory values for insolvency evaluation purposes.

According to data on foreign countries (Tab. 1), statutory ratio of current liquidity is too high in terms of Resolution of the RF Government of May 20, 1994 № 498. 
As mentioned in the research referred hereinafter [2], it is important to assess the current ratio for risk management and compliance with transparent operations requirements banks set forth for borrowers. Liquidity is of special significance for financial planning of operations, when entities determine their future needs in liquid assets so to optimize procurement, sales and value building that subsequently generate cash flows.

Resolution of the RF Government On Rules for Claiming Obligations to the Russian Federation as Part of Bankruptcy Cases and Bankruptcy Proceedings of April 15, 2003 № 218 superseded Resolution of the RF Government № 498 of May 20, 1994. However, a great deal of publications interlink the insolvency evaluation and liquidity and use indicators envisaged in Resolution of May 20, 1994 № 498 as insolvency indicia. For instance, as mentioned in Addendum 2, paragraph 3 of Resolution of the Central Bank of Russia № 254-П of March 26, 2004, comparative data... containing information...on liquidity (solvency)...

Imperfections of the regulatory framework and organizational procedures made the legislature revise the law. In 1998, law-makers adopted a new edition of the law on insolvency (bankruptcy).

The 1998 and 2002 editions of the law on insolvency provide for a different bankruptcy criterion. Unsatisfactory structure of the balance sheet and its due recognition as such no longer entailed any legal implications and ceased to be used for reference purposes, since corporate ability/inability to pay became the criterion for corporate solvency.

As per the 1998 and 2002 editions of the law on insolvency (bankruptcy) and the Order of the Federal Service for Financial Recovery ${ }^{3}$, the extent to which the entity is able to pay under its current obligations $\left(K_{9}\right)$ is the ratio of current borrowings of the entity (current liabilities) to the average monthly revenue $\left(K_{1}\right)$ :

$$
K_{9}=\frac{\text { Line } 1500(\text { Form } 0710002)}{K_{1}} \leq 3 \text { ， }
$$

$K_{1}=N / T$,

where $N$ stands for gross revenue of the entity from payments;

$T$ stands for the number of months within the period in question.

\footnotetext{
${ }^{3}$ Order of the Russian Federal Service for Financial Recovery On Approval of Methodological Guidelines for Analyzing Financial Position of Enterprises of January 23, 2001 № 16.
}

Average monthly revenue is assessed through gross revenue, including revenue from sale for the reporting period (from payments), VAT, excise taxes and other statutory payments. It indicates the volume of corporate income for the period and determines the main financial resource of the entity (business size), which is used to carry out operations, and inter alia fulfill obligations to fiscal authorities of the State, other entities, and employees. Net revenue is carried in Line 2110 of the statement of financial results.

The ratio reflecting the current solvency of strategically important organizations shall be less than or equal to 6 .

In this respect, a set of indicators for analyzing the financial position and assessment methods were considered in our previous researches ${ }^{4}$ [3].

Credit Review. Creditworthiness (the ability to repay) stands for the entity's ability to discharge its liabilities using available assets. Creditworthiness is closely related to liquidity indicators. Indicators of absolute, critical, current liquidity are used.

Current ratio shows the entity's ability to pay, which is assessed through the sale of other items of tangible current assets, if needed, rather than only through timely payment of accounts receivable and successful sale of finished goods. The current ratio indicates how many Rubles of current assets account for one Ruble of current liabilities and reflects the expected ability of the entity to pay within the period that is equal to the average time it takes all current assets to make one turnover. The ratio depends on the duration of the production cycle, mix of inventories, costs and some other factors. The following statement is advisable for it:

$$
1 \leq k_{\text {cur .lqdt }} \leq 2
$$

The lower bound means that current assets shall suffice to discharge current liabilities. However, if the amount of current assets is twice greater than current liabilities, it is evidence that the entity made unreasonable investment and used it ineffectively. The advisable ratios reflecting current liquidity shall depend on the specifics of the entity's activities, format of payments for goods and services, duration

\footnotetext{
${ }^{4}$ Lyubushin N.P., Babicheva N.E. [Analyzing methods to evaluate financial standing of the entity]. Ekonomicheskii analiz: teoriya i praktika $=$ Economic Analysis: Theory and Practice, 2006, no. 22, pp. 2-7. (In Russ.); Pankov V.V. [Analyzing the content of certain indicators of financial standing of a business]. Ekonomicheskii analiz: teoriya i praktika $=$ Economic Analysis: Theory and Practice, 2004, no. 1, pp. 2-9. (In Russ.)
}

Please cite this article as: Endovitskii D.A., Lyubushin N.P., Babicheva N.E., Kupryushina O.M. From Assessment of Organization's Financial Standing to Integrated Methodology for Analysis of Sustainable Development. Digest Finance, 2017, vol. 22, iss. 2, pp. 123-143. Available at: https://doi.org/10.24891/df.22.2.123 
of the production cycle, structure of inventories. Such specifics was mentioned by V.V. Pankov stating that he analyzed results of assessments based on various techniques and found that the ratio ranged significantly... The variability stems from different understanding some authors have on the way current assets and current liabilities are accrued for purposes of financial reporting. Thereafter the researcher says that L.T. Gilyarovskaya provides the most appropriate calculus of the current ratio. L.T. Gilyarovskaya assesses current assets by excluding amounts due from members (shareholders) for contributions to the authorized capital and treasury stocks bought back from shareholders ${ }^{5}$.

Nevertheless, $k_{\text {cur.lqd }}$ ranging from 1.3 through 1.7 is acceptable for international (Tab. 1) and Russian practices, thus ensuring uninterrupted production and sale of products.

As per subparagraph 3.2 of Resolution of the Central Bank of Russia № 254-П, the borrower's financial position is assessed using the technique (techniques) approved by internal regulations of the credit institution and harmonized with clauses of the above Resolution. Financial position is defined as follows:

- good in case of stable production, positive net assets, profitability and solvency, absence of any negative triggers (trends) that may influence the borrower's financial stability in the future;

- moderate in case of absence of direct threats to the current financial position, notwithstanding negative trends in the borrower's operations, which may lead to financial difficulties in a short run (year or even less), unless the borrower undertakes relevant measures;

- bad if the borrower is regarded as insolvent in accordance with the legislation, persistently insolvent or known to suffer from negative and threatening trends, which may result in insolvency.

The description of good and bad financial standing includes the concept of solvency.

As revealed by an analysis of techniques that major banks use to evaluate creditworthiness (Sberbank, Alfa-Bank, UralSib, SvyazBank, PromSvyazBank) in the monograph edited by D.A. Endovitskii, those

\footnotetext{
${ }^{5}$ Pankov V.V. [Analyzing the content of certain indicators of financial standing of a business entity]. Ekonomicheskii analiz: teoriya i praktika = Economic Analysis: Theory and Practice, 2004, no. 1, pp. 2-9. (In Russ.)
}

techniques lack the main indicator of corporate solvency, i.e. current solvency indicator [4]. We would like to stress that this indicator is the only one that has statutory value in accordance with the Law On Insolvency (Bankruptcy) as edited in 1998 and 2002 (See Article 3, paragraph 2 in the 2002 edition of the Federal Law).

Financial Sustainability. Financial sustainability is one of the most vital descriptors of the entity's financial standing. This article draws upon the paper analyzing methods and models for evaluating the financial sustainability of organizations as studied in proceedings by the Russian and foreign authors ${ }^{6}$.

As stated by L.T. Gilyarovskaya, the concept of financial sustainability of the entity has multiple facets. It is much more diversified than the concepts of solvency and creditworthiness, since it implies an evaluation of various aspects of corporate operations [5, p. 9].

The same feature is noted in proceedings by M.A. Bendikov, I.V. Sakharova, E.Yu. Khrustalev. Their studies focus on financial and economic sustainability ${ }^{7}$. Considering the above, Fig. 2 presents factors of the entity's financial sustainability.

Financial sustainability of the entity is assessed with approaches indicated in Fig. 3.

As inferred in researches, the evaluation of financial sustainability mainly relies upon the ratio-based method (relative indicators). According to L.A. Bernstein, ratios are among the most popular and widely used tools for financial analysis [6, p. 67]. As noted by Ya.V. Sokolov, there were a lot of attempts, though mostly fruitless, to expand the methodological spectrum of financial reporting analysis. However, it mainly contains a set of the so called vertical and horizontal ratios ${ }^{8}$.

The golden rule of economics is also applicable to evaluation of financial sustainability. The entity is financially viable if it accumulates its economic

\footnotetext{
${ }^{6}$ Lyubushin N.P., Babicheva N.E., Galushkina A.I., Kozlova L.V. [Analyzing methods and models for evaluating financial statements of entities]. Ekonomicheskii analiz: teoriya i praktika = Economic Analysis: Theory and Practice, 2010, no. 1, pp. 3-11. (In Russ.)

${ }^{7}$ Bendikov M.A., Sakharova I.V., Khrustalev E.Yu. [Financial and economic sustainability of the enterprise and regulation methods]. Ekonomicheskii analiz: teoriya i praktika = Economic Analysis: Theory and Practice, 2006, no. 14, pp. 5-14. (In Russ.)

${ }^{8}$ Sokolov Ya.V. Bukhgalterskii uchet: ot istokov do nashikh dnei [Accounting: From origins to current days]. Moscow, Audit, YUNITI Publ., 1996, p. 407.
} 
capabilities, that is, it meets the conditions of the following dynamic criterion:

$$
\frac{d P^{p}}{d t}>\frac{d N^{p}}{d t}>\frac{d S^{\prime}}{d t}
$$

where $P^{p}$ is sales profit;

$N^{p}$ is the volume of sales (revenue);

$S^{\prime}$ is the cost (full).

Traditional Approach. The traditional approach involves indicators of corporate assets, sources of their formation and other aspects of financial and economic activities, without grouping them by certain criterion. The most comprehensive review of the traditional approach is given in the research referred hereinafter [6] and other scholarly articles ${ }^{9}$, regulatory methodologies ${ }^{10}$.

In its methodological guidelines, the Russian Federal Service for Financial Recovery consolidates indicators of solvency and financial sustainability into one group that includes 10 ratios:

- coverage ratio;

\footnotetext{
${ }^{9}$ Endovitskii D.A., Endovitskaya A.V. [Systems approach to analyzing financial sustainability of a business]. Ekonomicheskii analiz: teoriya $i$ praktika = Economic Analysis: Theory and Practice, 2005, no. 6, pp. 2-7. (In Russ.); Bukhonova S.M., Doroshenko Yu.A., Benderskaya O.B. [Comprehensive methods for analyzing financial sustainability of the entity]. Ekonomicheskii analiz: teoriya i praktika = Economic Analysis: Theory and Practice, 2004, no. 7, pp. 8-15. (In Russ.); Karapetyan A.L., Mudrak A.V. [Evaluating the entity's financial position through the uniform system of coefficients]. Ekonomicheskii analiz: teoriya $i$ praktika = Economic Analysis: Theory and Practice, 2005, no. 4, pp. 28-35. (In Russ.); Karapetyan A.L., Mudrak A.V. [On Developing an alternative approach to analyzing financial sustainability of a business]. Ekonomicheskii analiz: teoriya i praktika $=$ Economic Analysis: Theory and Practice, 2005, no. 16, pp. 32-39. (In Russ.); no. 17, pp. 36-40. (In Russ.); Glazunov M.I. [Evaluating financial sustainability of a profit-making entity through the balance sheet]. Ekonomicheskii analiz: teoriya $i$ praktika $=$ Economic Analysis: Theory and Practice, 2009, no. 21, pp. 58-67. (In Russ.); Risin I.E., Treshchevskii Yu.I. [Applying forecasting models for the $K$-index in financial analysis of entities]. Ekonomicheskii analiz: teoriya i praktika = Economic Analysis: Theory and Practice, 2004, no. 3, pp. 21-26. (In Russ.); Lyubushin N.P., Bezborodova T.I. [The use of foreign experience to evaluate the entity's financial position for crisis management]. Ekonomicheskii analiz: teoriya i praktika = Economic Analysis: Theory and Practice, 2004, no. 11, pp. 2-6. (In Russ.)

${ }^{10}$ RF Federal Law On Insolvency (Bankruptcy) of October 26, 2002 № 127-Ф3; Order of the Russian Federal Service for Financial Recovery On Approval of Methodological Guidelines for Analyzing Financial Positions of the Entity of January 23, 2001 № 16; Resolution of the RF Government On Approval of Rules for Court-Appointed Administrators to Perform Financial Analysis of June 25, 2003 № 367; Resolution of the RF Government On Grouping of Entities In Case of Bankruptcy Threats for Strategically Important Entities of April 21, 2006 № 104; Resolution of the RF Government On Enforcement of the Federal Law On Financial Recovery of Agricultural Producers of January 30, 2003 № 52.
}

- ratio of the sum of non-current liabilities, short-term bank loans and borrowings to average monthly revenue;

- ratio of the sum of liabilities in Lines Trade Payables and Accounts Payable to average monthly revenue;

- ratio of the sum of amounts due to governmental extrabudgetary funds and taxes payable to average monthly revenue;

- ratio of the sum of amounts due to employees, shareholders, deferred income, provisions for future expenses, other current liabilities to average monthly revenue;

- ratio of short-term borrowings (current liabilities) to average monthly revenue;

- current ratio;

- difference between equity net of noncurrent assets;

- ratio of the equity in turnover to all current assets;

- equity-to-total assets ratio.

D.A. Endovitskii ${ }^{11}$ articulated a system for comprehensive analysis of financial sustainability of the entity. The system comprises 14 blocks (Fig. 4).

Block 1 denotes a preliminary analysis of property and financial position, performance results and cash flow of the entity. It is followed by a consolidated module of eight blocks, i.e. factor analysis of financial sustainability.

A similar approach was used in the research by S.M. Bukhonova, Yu.A. Doroshenko, O.B. Benderskaya, but they also assessed the integral indicator (Fig. 5). Assessment of the integral indicator reveals what strengths and weaknesses of the entity in outlining a development program. This method also implies a comparative evaluation of the financial sustainability level so to determine what position the entity has in ratings.

This method has the following drawbacks:

- variety of ratios results from different sources of information authors use;

- significance of each ratio depends on experts' qualification;

\footnotetext{
${ }^{11}$ Endovitskii D.A., Endovitskaya A.V. [Systems approach to analyzing the entity's financial sustainability]. Ekonomicheskii analiz: teoriya i praktika = Economic Analysis: Theory and Practice, 2005, no. 6, pp. 2-7. (In Russ.)
}

Please cite this article as: Endovitskii D.A., Lyubushin N.P., Babicheva N.E., Kupryushina O.M. From Assessment of Organization's Financial Standing to Integrated Methodology for Analysis of Sustainable Development. Digest Finance, 2017, vol. 22, iss. 2, pp. 123-143. Available at: https://doi.org/10.24891/df.22.2.123 
- financial reporting-based ratios reflect retrospective data, thus driving down the quality of evaluation;

- the use of different rating methods results in ambiguous results.

Proceedings by A.L. Karapetyan and A.V. Mudrak present the original method for evaluating the financial sustainability - indicative method that forms indicative matrices $^{12}$. As seen in further publications, the method was not widespread.

As one of the financial sustainability criteria, we should mention an excess or lack of sources of funds for the formation of inventories (tangible current assets).

Proceedings by M.I. Bakanov, A.D. Sheremet, V.V. Kovalev ${ }^{13}$ and other scholars note that the correlation of inventories and sources of their formation represents the substance of financial sustainability, meanwhile solvency is just an external indicator. Whereas inventories are formed with working capital, a special focus shall be put on the specifics of their assessment, as indicated in the paper by M.I. Glazunov ${ }^{14}$.

There are four types of financial sustainability ${ }^{15}$ :

- absolute stability of financial position, i.e. total working capital $E^{w C}$ and short-term loans and borrowings $C^{L B}$ exceeds the demand for inventories $E^{\prime}: E^{\prime}<E^{W C}+C^{L B}$

- adequate stability, i.e. the ability to pay is assured given $E^{\prime}=E^{W C}+C^{L B}$. The amount of inventories is

\footnotetext{
${ }^{12}$ Karapetyan A.L., Mudrak A.V. [Evaluating the entity's financial position using the uniform system of ratios]. Ekonomicheskii analiz: teoriya i praktika = Economic Analysis: Theory and Practice, 2005, no. 4, pp. 28-35. (In Russ.); Karapetyan A.L., Mudrak A.V. [On the development of an alternative approach to analyzing the financial sustainability of the profit-making entity]. Ekonomicheskii analiz: teoriya i praktika = Economic Analysis: Theory and Practice, 2005, no. 16, pp. 32-39. (In Russ.); no. 17 , pp. 36-40. (In Russ.)

${ }^{13}$ Sheremet A.D. Teoriya ekonomicheskogo analiza [The theory of economic analysis]. Moscow, INFRA-M Publ., 2002, 333 p.; Bakanov M.I., Sheremet A.D. Metodika ekonomicheskogo analiza [Methods of economic analysis]. Moscow, Finansy i Statistika Publ., 1999, 416 p.; Kovalev V.V., Volkova O.N. Analiz khozyaistvennoi deyatel'nosti predpriyatiya [Analyzing business operations of the entity]. Moscow, Velbi, Prospekt Publ., 2004, 424 p.

${ }^{14}$ Glazunov M.I. [Evaluating the financial sustainability of the profitmaking entity using the balance sheet]. Ekonomicheskii analiz: teoriya i praktika = Economic Analysis: Theory and Practice, 2009, no. 21, pp. 5867. (In Russ.)

${ }^{15}$ Sheremet A.D. Teoriya ekonomicheskogo analiza [The theory of economic analysis]. Moscow, INFRA-M Publ., 2002, 333 p.
}

sufficient to repay short-term loans and borrowings and have working capital;

- unstable financial position, i.e. the balance of payment is disrupted, but it is still possible to recover the balance of funds and payment obligations by involving temporarily free sources of funds $\left(C^{S F}\right)$ into the entity's turnover (surplus capital, accumulation and consumption funds, bank loans and borrowings for temporary replenishment of working capital and other sources that can address financial constraints): $E^{\prime}=E^{W C}+C^{L B}+C^{S F}$;

- financial crisis, i.e. the current solvency is more than three. It means that monetary funds, short-term financial investment and accounts receivable of the entity are not sufficient to discharge accounts payable and overdue borrowings, i.e. $E^{\prime}>E^{W C}+C^{L B}+C^{S F}$. The balance of payments may be restored in this situation by delaying the payment of salaries, repayment of bank loans and borrowings, trade payables, taxes payable, etc.

Methods and Models Based on Stochastic Analysis. Based on financial analysis, the set of indicators allows to identify weaknesses in financial and business activities of the entity and determine its financial sustainability. While some indicators may be out of tolerable thresholds, the other may be quite satisfactory. The analysis does not provide a definite answer whether the entity loses its financial sustainability in the nearest future or, on the contrary, it grows. We can make some conclusions if we compare indicators of the entity and other entities that went bankrupt or avoided bankruptcy ${ }^{16}$. However, it is rather difficult and sometimes impossible in Russia to find an identical example to compare in each particular case. The loss of financial sustainability can be predicted more reliably and accurately, if we forecast the probability of the loss of the entity's financial sustainability using stochastic analysis methods, in addition to the financial analysis ${ }^{17}$.

We should note that it is of no practical use for the Russian entities to apply numerical value of foreign criteria for multivariate models. The models are based on a discriminant analysis of statistical data of entities from certain countries where the market

\footnotetext{
${ }^{16}$ In this particular case, insolvency (bankruptcy) is considered as the loss of financial sustainability, financial crisis of the firm.

${ }^{17}$ Lyubushin N.P., Leshcheva V.B., Suchkov E.A. Teoriya ekonomicheskogo analiza [The theory of economic analysis]. Moscow, Yurist" Publ., 2002, 480 p.
} 
economy has its own specifics. This was proved in the research by I.E. Risin and Yu.I. Treshchevskii ${ }^{18}$. Illustrating a certain entity, they evaluated the probability of its bankruptcy using models developed by Altman, Lis, Taffler, Zaitseva, Saifullin and Kadykov. The outcome showed the discrepancy and divergence of forecasts.

The loss of financial sustainability (bankruptcy risk) can be analyzed provided that the following conditions are met:

- the analysis draws upon observations made for as a long period of corporate operations as possible;

- data for the analysis shall give a reliable and accurate view of the entity's financial position;

- the analysis involves only those indicators that serve as the best evidence of the possible loss of the entity's sustainability;

- the analysis required representative statistics on bankruptcy instances, which shall be statistically homogeneous in terms of the following factors: organizational and technological level of the entity, type of economic activity, period to be analyzed and so on.

Financial sustainability of Russian entities can be forecasted using methodological approaches to setting multifactor models for bankruptcy prediction. For higher precision of results, it is necessary to constantly adjust a set of indicators and weight coefficients of each indicator in line with the type of economic activity and other above mentioned conditions. It requires ongoing monitoring of entities' financial position, thus allowing to set Russia-specific models for forecasting financial sustainability and providing reliable and unbiased results.

Resource-Based Approach. As part of the resource-based approach, resources are considered as production factors accumulated for attaining desired results. There are labor, material, financial, information, intellectual resources, etc. Their availability, composition and efficiency of their use shape the sales volume (revenue), profit, cost, i.e. the development of any modern systems depends on the efficient use of resources.

\footnotetext{
${ }^{18}$ Risin I.E., Treshchevskii Yu.I. [Applying $K$-models for forecasting as part of the financial analysis of entities]. Ekonomicheskii analiz: teoriya i praktika = Economic Analysis: Theory and Practice, 2004, no. 3, pp. 21-26. (In Russ.)
}

In this respect, the development paradigm of economic systems changed, transforming them into a set of resources and competences, rather than a number of business processes. According to V.S. Kat'kalo [7], contemporary researches into the resource concept are believed to begin after B. Wernerfelt, Professor of High School of Business of the Michigan University, released his article, A Resource-Based View of the Firm, in 1984.

The resource-based approach highlights the unique nature of each entity and assumes that the efficiency can be achieved if the entity makes use of differences between other entities, rather than tries to reproduce their model. That is, it should draw upon the unique composition of resources, intensify their use and organizational capabilities.

G.B. Kleiner provides profound insights into this subject [8]. As he notes, the resource-based view, as a part of the theory of the firm, became a strong intellectual stream merging together methodology of economic analysis and management of economic units at different levels and with different goals. The author refers to papers of renowned foreign researchers [9-15].

Subsequently, economic units with different levels and goals will be called the skeleton for systemic sustainability of Russia's economy (State-Region-Industry-Enterprise) [16].

As a rule, it is impracticable to use a great deal of indicators (visibility principle) to evaluate and forecast the corporate development. Indicators can trace back to groups of different economic substance and purpose, but their purpose describes the type of economic development of the production in accordance with the structure and dynamics of resource-use indicators [17, p. 33].

Various combinations of sales trends (production), resources consumed and their output shape the type of production development and reveal indicators that describe the entity's financial sustainability (Fig. 6, 7).

Percentage of extensive and intensive factors can be computed using the determinant factor analysis (index method). As per the index method, the effect of the quantitative factor is initially assessed (Fig. 7).

The method turned to be effective in practices of some entities, and especially in case of vertically integrated

Please cite this article as: Endovitskii D.A., Lyubushin N.P., Babicheva N.E., Kupryushina 0.M. From Assessment of Organization's Financial Standing to Integrated Methodology for Analysis of Sustainable Development. Digest Finance, 2017, vol. 22, iss. 2, pp. 123-143. Available at: https://doi.org/10.24891/df.22.2.123 
structures, when subsidiaries the pricing of ultimate products ${ }^{19}$.

The entity's financial sustainability is viewed in the context of the following question. When does the financial position deteriorate? As part of the approach, it happens in case of extensive factors in production development (usage of resources). The existence of extensive factors indicates that the entity has reserves, which, if used, will drive the entity out of the coming crisis.

Having analyzed the existing and new systems, we concluded that systemic and structural sustainability of complex systems of production, economy, painting, music and other areas required that key systems indicators be in the golden ratio [18, p. 180]. As indicated by E.M. Soroko, ideas of harmony, its proportions, the golden mean of 0.618 have been agitating intellectual circles for more than 3,500 years $[19$, p. 3].

Suggestions to consider the golden ratio pertain to scientific schools led by V.I. Arnold [20], I.V. Prangishvili [18], A.V. Zhirmunskii, V.I. Kuz'min [21], V.V. Bushuev [22] and other scholars who proved that extremes deviated, to a certain extent, from traditionally accepted 100 percent of the factor effect. The hypothesis is corroborated with conclusions referring to the theory of catastrophes, Fibonacci numbers, Feigenbaum constants, S-curves.

As the mathematically proven theory holds, systems are stable only within a range from $1 / 3$ through $2 / 3$, i.e. from 33.3 through 66.6 percent. Otherwise their instability sharply rises and control is lost. Adhering to the thresholds is of paramount importance for the economy.

We shall specify the given classification of economic development types of production, sticking to the golden ratio principle (Tab. 2).

The USSR scientists actively unfolded the above approach to analyzing the production in terms of its economic development types. We should point

\footnotetext{
${ }^{19}$ Lyubushin N.P., Romanova I.V. [Functional approach to analyzing the financial position of the entity]. Ekonomicheskii analiz: teoriya i praktika $=$ Economic Analysis: Theory and Practice, 2006, no. 6, pp. 2-5. (In Russ.); Lyubushin N.P., Babicheva N.E. [Analyzing methods to evaluate the financial position of the entity]. Ekonomicheskii analiz: teoriya i praktika = Economic Analysis: Theory and Practice, 2006, no. 22, pp. 2-7. (In Russ.); Lyubushin N.P., Levshin G.V. [Analyzing financial sustainability of vertically integrated organizations using management accounting data]. Ekonomicheskii analiz: teoriya i praktika = Economic Analysis: Theory and Practice, 2008, no. 5, pp. 2-7. (In Russ.)
}

out proceedings by S.B. Barngol'ts, V.I. Ganshtak, S.E. Kamenitser, V.P. Kopnyaev, M.V. Mel'nik, R.M. Petukhov et al.

Resource Management Quality Approach. The better the business is managed, the more efficiently resources are used. This idea is missing in the previous methods for sustainability evaluation.

Poor corporate governance may engender a crisis situation. In this respect, the requirement to accumulate the economic potential should be coupled with the following condition. Administrative expenses for the production output should not grow faster than specific consumption of resources needed to manufacture the same volume of products:

$$
\frac{d P^{p}}{d t}>\frac{d N^{p}}{d t}>\frac{d S^{\prime}}{d t} ; \text { if } \frac{d S^{\mathrm{mngt}}}{d t} \leq \frac{d S^{\mathrm{dir} . c o s t}}{d t},
$$

where $d S^{\text {mngt }} / d t$ stands for the growth rate of administrative expenses;

$d S^{\text {dir.cost }} / d t$ stands for an increase in direct costs for resources.

Based on studies into methods and models for evaluating the entity's financial sustainability that rely upon the ratio method, it enables us to point out conditions and indicators of financial sustainability.

Significance of indicators varies due to external environment where the entity operates.

The methodological approach (based on specific weight of intensive factors in revenue, the firm is attributed to a certain type of economic development in terms of resources in question and a type of financial sustainability) was used to identify the following parameters: a stage of the entity's life cycle production, risk of resource use intensity, financial position. We also examined these aspects in some of our papers ${ }^{20}$.

The method can be considered as integrated, since it implies a very holistic approach to determining possible states of the entity.

The first stage of the method (Fig. 7) allocates resources ( $i$-types) used to run the production cycle of the entity and evaluates the efficiency of their use.

\footnotetext{
${ }^{20}$ Babicheva N.E. [Integrated methods for economic analysis of the corporate development using the resource-based approach]. Ekonomicheskii analiz: teoriya i praktika = Economic Analysis: Theory and Practice, 2013, no. 1, pp. 10-18. (In Russ.); Endovitskii D.A., Lyubushin N.P., Babicheva N.E. [Resource-oriented economic analysis: theory, methodology, practice]. Ekonomicheskii analiz: teoriya i praktika = Economic Analysis: Theory and Practice, 2013, no. 38, pp. 2-8. (In Russ.)
} 
We found four groups reflecting how revenue depends on resources used, and set up 30 models:

- models showing the dependence of revenue on the effectiveness of cost (expense) items (groups);

- models showing the dependence of revenue on the efficiency of asset utilization;

- models showing the dependence of revenue on the efficiency of receivables and financial investment;

- models showing the dependence of revenue on the efficiency of labor resource use.

The above models were tested in a number of entities, proving their workability [23, pp. 200-220].

Development of the Resource-Based Approach in Line with the Concept of Sustainable Development. We have presented our views on the issue in a number of papers ${ }^{21}$. The concept of sustainable development of economic systems goes back to The Limits to Growth prepared by the Club of Rome in 1972. The report elucidated issues of economic growth, development, education, consequences of new technologies. The report made the first mention of natural resource depletion, decline of the industry growth and called for a new concept of global sustainable development [24]. As a result, many countries adopted laws on environmental protection, started the relocation of industrial production from large cities, closed hazardous production, etc.

Starting from the 1980s, the global community has acquired a broader view on the development. New approaches have been forged for the recent decades. Such development criteria as the freedom of choice in its broad sense, non-economic components (environmental, institutional, etc.) grew more important.

In 1987, the World Commission on Environment and Development chaired by Gro Harlem Brundtland released the report, Our Common Future, which defined the sustainable development as a model driving us

\footnotetext{
${ }^{21}$ Lyubushin N.P., Babicheva N.E. et al. [Modeling the sustainable development of different hierarchical level economic systems based in a resource-oriented approach]. Ekonomicheskii analiz: teoriya $i$ praktika = Economic Analysis: Theory and Practice, 2015, no. 48, pp. 2-12. (In Russ.); Lyubushin N.P., Babicheva N.E. et al. [Genesis of the concept of sustainable development of economic systems of various hierarchical levels]. Regional'naya ekonomika: teoriya i praktika = Regional Economy: Theory and Practice, 2015, no. 48, pp. 2-14. (In Russ.)
}

forward and satisfying living needs of the current generation without depriving future generations of this opportunity. At the UN Conference on Environment and Development (Rio de Janeiro, 1992), participants recognized the concept of sustainable development of the humanity and stipulated its main principles in Agenda 21. As stated in Agenda 21, the concept relies on three components, i.e. environmental, economic and social ones. As mentioned by N.N.Marfenin, the expression sustainable development of humankind synthesized three humanistic principles of the world evolution in the second half of the 20th century, i.e. pacifism, democratization, environmental revolution in minds and economy [25, p. 171]. As the concept runs, environmental issues are insolvable without addressing social and economic issues and understanding the sustainable development in the broad context.

In our opinion, the International Integrated Reporting Framework complies with the said principles. It was analyzed in a number of papers, especially featuring researches by V.G. Get'man, V.G. Kogdenko and M.V. Mel'nik ${ }^{22}$. They unveil the concept of integrated reporting, its purpose, difference from financial reporting, content. As put in the International Integrated Reporting Framework, entities' main objective is to create value in the interests of all stakeholders, increasing all types of capital. The Framework indicates six types of capital, i.e. financial, manufactured, intellectual, social and relationship, natural. According to A.D. Sheremet, currently researchers are on the way to the fourth stage of business analysis, i.e. an analysis of corporate sustainable development indicators from economic, social and environmental perspectives simultaneously. It is reasonable to develop methods for analyzing how environmental and social indicators influence the financial and economic ones in addition to those examined in handbooks of comprehensive economic analysis $^{23}$. To evaluate the sustainable development of entities using the algorithm depicted in Fig. 8, we

\footnotetext{
${ }^{22}$ Get'man V.G. [On conceptual principles and structure of the International Integrated Reporting Standard]. Mezhdunarodnyi bukhgalterksii uchet = International Accounting, 2014, no. 44, pp. 2-15. (In Russ.); Kogdenko V.G., Mel'nik M.V. [Integrated reporting: issues of formation and analysis]. Mezhdunarodnyi bukhgalterksii uchet = International Accounting, 2014, no. 10, pp. 2-15. (In Russ.)

${ }^{23}$ Sheremet A.D. [Comprehensive analysis of indicators of the entity's sustainable development]. Ekonomicheskii analiz: teoriya i praktika = Economic Analysis: Theory and Practice, 2014, no. 45, pp. 2-10. (In Russ.)
} 
should additionally perform an analysis of how environmental and social indicators influence the revenue.

The effect of environmental indicators (natural capital) is studied in the paper by M.V. Mel'nik and V.G. Kogdenko ${ }^{24}$. As its focal point, the research proves that the effect evaluation includes some principles typical of the method for analyzing the production capital. For instance, the researchers introduce the indicators reflecting the return on nature (ratio of revenue to volume or cost of natural capital utilized), thus making it possible to assess how intensively the entity uses this capital. That is, at Stage 1 (Fig. 8) the dependence of revenue on natural capital indicators is introduced.

Unfortunately, there is not an identical method for social indicators.

The algorithm in Fig. 8 describes sustainable development of the entity in relation to those types of resources, where it is possible to assess the efficiency of their use through the specific weight of intensive factors in revenue. We add Stage 8 - Evaluation of the entity's sustainable development through the efficiency of using the $i$-type of resources. Sustainable development is regarded as a process and state. As a process, sustainable development takes a certain period of time, when its parameters change. Specific weight of intensive factors in revenue in relation to a certain type of resources constitutes the key characteristic under the methodological approach. This characteristic is invariant of sustainable development. Adhering to the earlier accepted classification, we shall define development sustainability as absolutely sustainable, stable, unsustainable and crisis.

According to V.I. Danilov-Danil'yan, the development (civilization, country, region, social group, economic system, etc.) within any foreseeable period of time shall be deemed stable if it remains invariant, i.e. it does not change, threaten any quality, object, relationship [26]. As formulated by N.P. Lyubushin, N.E. Babicheva, the invariant indicates the intensive type of economic systems development. Hence, the development should be intensive and extensive, increasing the effect of the intensive type of economic development on results. Premises for the statement were

\footnotetext{
${ }^{24}$ Mel'nik M.V., Kogdenko V.G. [Analyzing integrated reporting: natural capital]. Ekonomicheskii analiz: teoriya i praktika = Economic Analysis: Theory and Practice, 2016, no. 4, pp. 72-84. (In Russ.)
}

pronounced by G.B. Kleiner in the Resource-Based View of systemic organization of economy: the distribution of basic resources and capabilities among various types of systems allows to understand the activities of the systems as stylized production functions, which show how results depend on the size of basic resources used and the level of basic capabilities. We take $R \Sigma(t)$ as a general indicator of $\Sigma$-system performance during the period (at the moment) $t, \Sigma=a, \beta, y, \delta$. Whereas only $S$ is limited for $\delta$-object system out of two types of primary resources - $S$ (space) and $T$ (time), the result of $R \delta(t)$-object system in $t$-period can be expressed as follows:

$R \delta(t)=/ \delta(t) S \delta(t)$

where $I \delta(t)$ means how intensively $\delta$-system utilizes the spatial resource;

$S \delta(t)$ means the size of that resource [8].

This formula refers to the multiplicative model reflecting how the resultant indicator depends on qualitative and quantitative indicators. It has a definite solution to determine the type of economic development of economic systems as illustrated in numerous examples of N.E. Babicheva's monograph [23]. We spotlight this aspect, since some authors opine that, in the current circumstances, the division of factors into extensive and intensive is rather approximate [27, p. 144].

The creation of a comprehensive indicator reflecting the entity's sustainable development still remains a matter of controversy. As Yu.K. Perskii and V.V. Lephikhin state in their article ${ }^{25}$, having analyzed methodological approaches to evaluating corporate sustainability as a system of environmental, social and economic aspects, they found the ambiguity in construing the comprehensive indicator of sustainability and concluded that the comprehensive nature of indicators describing various sustainability aspects of different scale was the main obstacle to evaluating the development sustainability.

As proved in the article referred hereinafter [28], it is an irrelevant task to form the integral indicators. It will perhaps cause the loss of useful information for evaluating sustainable development trends. We

\footnotetext{
${ }^{25}$ Perskii Yu.K., Lepikhin V.V. [Methodological approaches to evaluating the entity's sustainability as a system of environmental, social and economic factors]. Natsional'nye interesy: prioritety 0 bezopastnost' = National Interests: Priorities and Security, 2014, no. 39, pp. 14-20. (In Russ.)
} 
believe that there should be a general model of sustainable development, which would be understandable and adapted to any specifics and reflect all operational aspects of economic agents having different hierarchical level. As for the integral indicator of financial sustainability, its creation identifies a number of drawbacks ${ }^{26}$ arising inter alia from the need in rating. A similar drawback appears when method and models of stochastic analysis are used.

It is worth mentioning the complexity of proceedings for the creation of a comprehensive indicator. As fairly noted by M.V. Mel'nik and V.G. Kogdenko, it necessitates analytical procedures to evaluate all types of capital, interactions among them, and assess the value of those types of capital and business as a whole ${ }^{27}$.

The research referred hereinafter [29] corroborates the extortion of the sustainable development concept perception at the level of economic agents. As the authors believe, the issue of sustainable development is broader at the corporate level, than economic, environmental and social aspects of business reviewed in isolation. The main problem is to adapt social aspects to evaluation of financial sustainability. Furthermore, if sustainable development indicators are devised, they will allow to set up the general framework for the accounting model of sustainable development so that they could be applicable at the corporate level, including the methodology for the model implementation and testing in particular business entities.
Analyzing approaches to evaluating the financial position of the Russian entities and their sustainable development, we can underline key challenges in this area of research:

- scarce researches investigating how development patterns and business operations correlate with the financial position and sustainable development;

- it is problematic to analyze activities of the Russian entities due to the absence of regulatory framework and average indicators describing the financial position in all types of economic activities (rating agencies in foreign countries prepare and release similar rates on a regular basis);

- reports of the entities studied are often misstated due to inflationary processes in the Russian economy, which mainly influence horizontal analysis, rather than vertical one (basic proportions remain unchanged). In this respect, the evaluation of financial and business activities requires the presentation of comparable values;

- absence of analytical procedures to evaluate all types of capital in integrated reporting, interactions among them and the value of business, as a whole;

- detailed elaboration of a corporate operations analysis entailed the development, calculation and application of the excessive number of indicators, considering that some of them are, to an extent, functionally interdependent (for instance, equity-to-asset ratio, gearing ratio).

\footnotetext{
${ }^{26}$ Bukhonova S.M., Doroshenko Yu.A. [Comprehensive methods for analyzing the entity's sustainability]. Ekonomicheskii analiz: teoriya i praktika = Economic Analysis: Theory and Practice, 2004, no. 7, pp. 8-15. (In Russ.)

${ }^{27}$ Mel'nik M.V., Kogdenko V.G. [Analyzing integrated reporting: natural capital]. Ekonomicheskii analiz: teoriya i praktika = Economic Analysis: Theory and Practice, 2016, no. 4, pp. 72-84. (In Russ.)
}

Please cite this article as: Endovitskii D.A., Lyubushin N.P., Babicheva N.E., Kupryushina O.M. From Assessment of Organization's Financial Standing to Integrated Methodology for Analysis of Sustainable Development. Digest Finance, 2017, vol. 22, iss. 2, pp. 123-143. Available at: https://doi.org/10.24891/df.22.2.123 


\section{Table 1}

The values of current liquidity ratio in developed countries

\begin{tabular}{lllll}
\hline Sector & USA & UK & Europe & Japan \\
\hline Light industry & 2.5 & 1.75 & 1.8 & 1.75 \\
\hline Food industry & 1.2 & 1.2 & 1.4 & 1.3 \\
\hline Machine building & 1.1 & 1.1 & 1.5 & 1.1 \\
\hline Trade & 1.7 & 1.4 & 1 & 1.1 \\
\hline Average & 1.3 & 1.2 & 1.2 & 1.15 \\
\hline
\end{tabular}

Source: Edronova V.N., Shakhvatova M.V. [Specifics of assessing the financial results and financial standing of the subjects of budgeting]. Ekonomicheskii analiz: teoriya i praktika = Economic Analysis: Theory and Practice, 2004, no. 13, pp. 2-9. (In Russ.)

Table 2

Classification of financial sustainability based on the Golden ratio principle depending on the type of economic development of production

\begin{tabular}{lll}
\hline Type of financial sustainability & Type of production development & $\begin{array}{l}\text { Bounds of changes in intensive } \\
\text { factors }\end{array}$ \\
\hline Absolute & Intensive & Over $62 \%$ \\
\hline Normal & Intensive-extensive & From 38 to 62\% \\
\hline Unsustainable financial position & Extensive-intensive & From 14 to 38\% \\
\hline Financial crisis & Extensive & Less than 14\% \\
\hline
\end{tabular}

Source:Authoring

Please cite this article as: Endovitskii D.A., Lyubushin N.P., Babicheva N.E., Kupryushina 0.M. From Assessment of Organization's Financial

134 Standing to Integrated Methodology for Analysis of Sustainable Development. Digest Finance, 2017, vol. 22, iss. 2, pp. $123-143$. Available at: https://doi.org/10.24891/df.22.2.123 


\section{Figure 1}

Changes in coefficients characterizing the solvency of organizations in 1995-2015, percentage

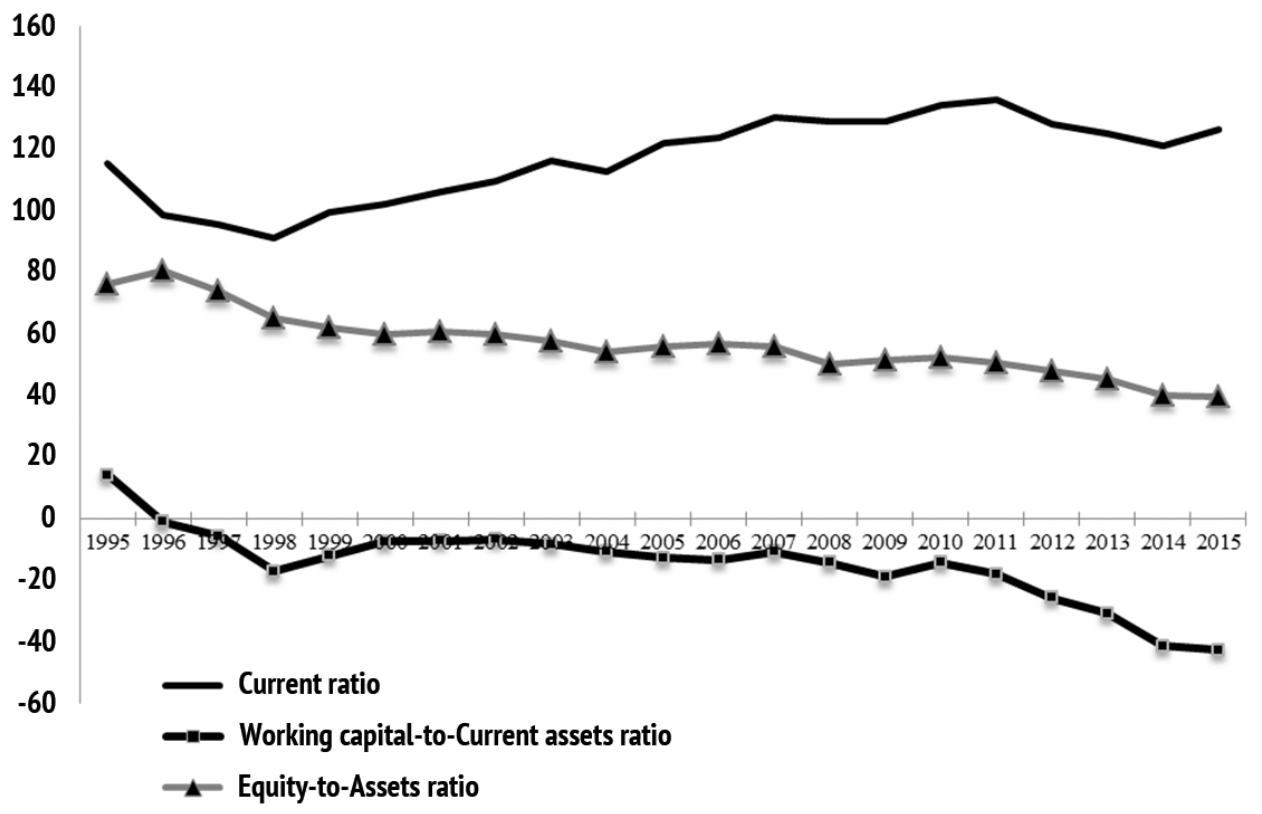

Source:Authoring, based on Rosstat data

\section{Figure 2}

The elements of financial sustainability of the organization

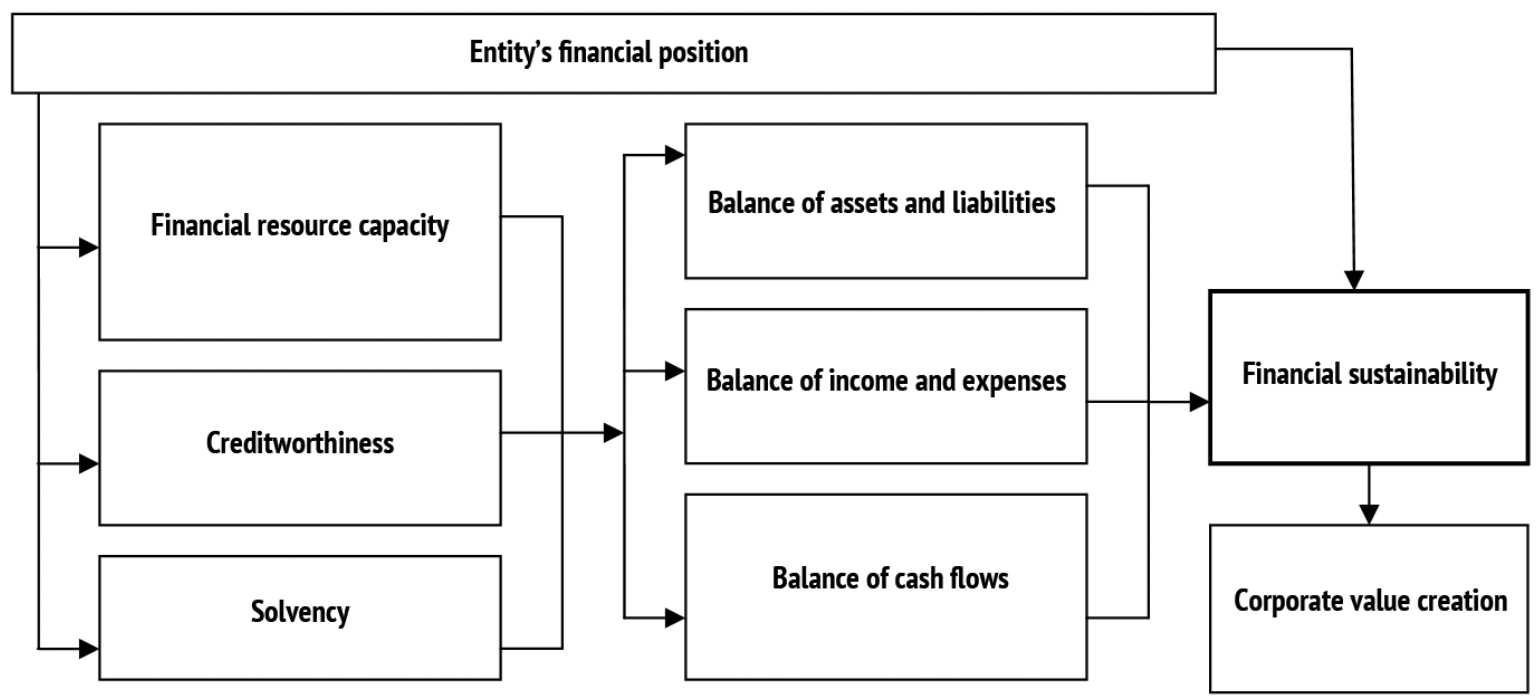

Source: Authoring

Please cite this article as: Endovitskii D.A., Lyubushin N.P., Babicheva N.E., Kupryushina O.M. From Assessment of Organization's Financial Standing to Integrated Methodology for Analysis of Sustainable Development. Digest Finance, 2017, vol. 22, iss. 2, pp. 123-143. Available at: https://doi.org/10.24891/df.22.2.123 


\section{Figure 3}

Approaches to assessment of organization's financial sustainability

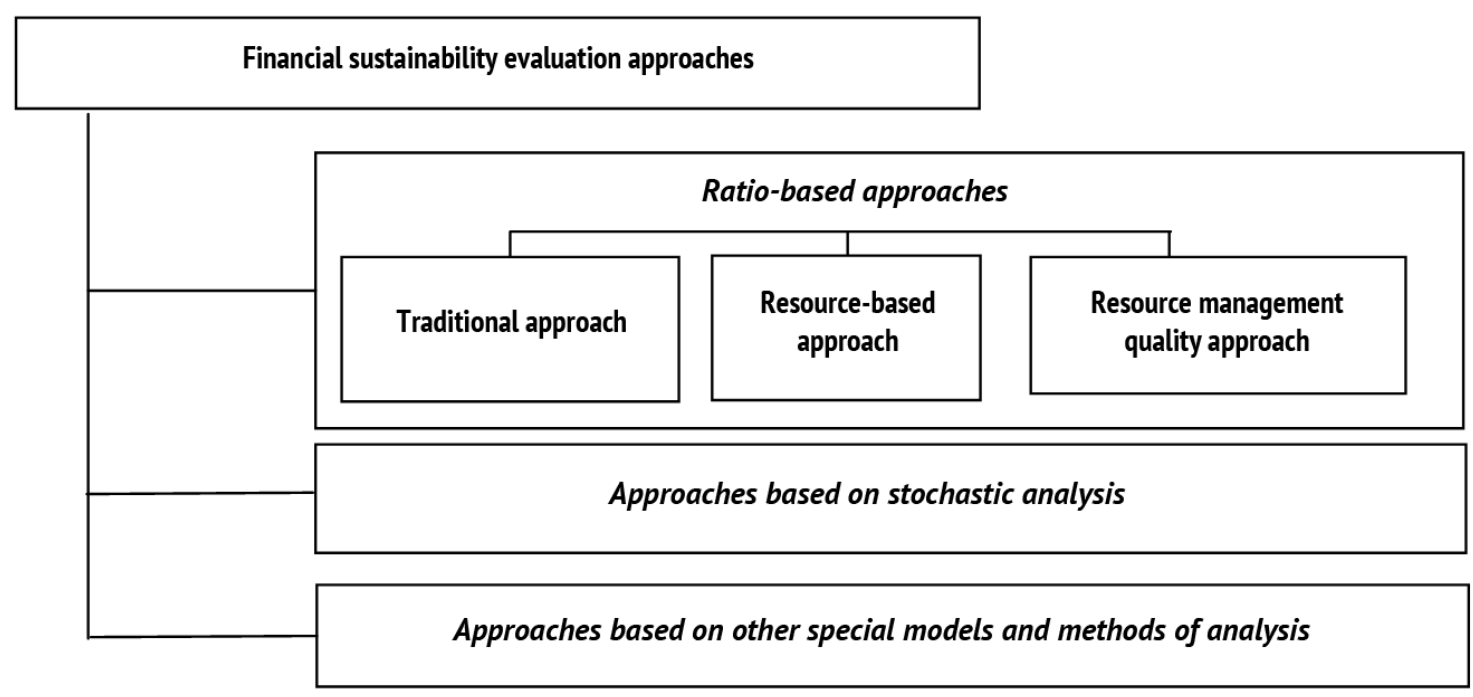

Source: Authoring

Please cite this article as: Endovitskii D.A., Lyubushin N.P., Babicheva N.E., Kupryushina 0.M. From Assessment of Organization's Financial 
Figure 4

A scheme of complex analysis of financial sustainability of the organization

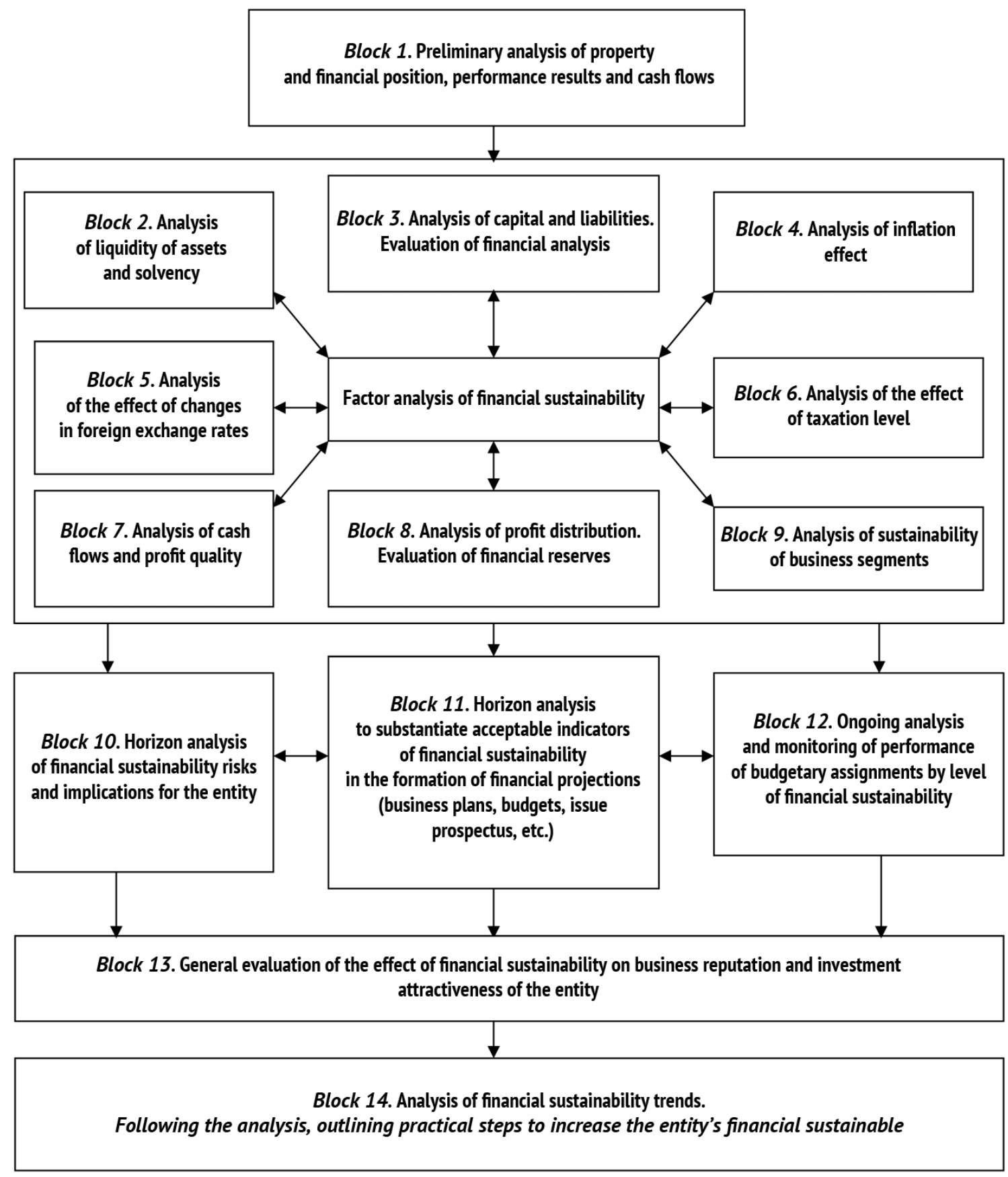

Source: Endovitskii D.A., Endovitskaya A.V. [A systems approach to the analysis of financial sustainability of commercial organizations]. Ekonomicheskii analiz: teoriya i praktika = Economic Analysis: Theory and Practice, 2005, no. 6, pp. 2-7. (In Russ.)

Please cite this article as: Endovitskii D.A., Lyubushin N.P., Babicheva N.E., Kupryushina O.M. From Assessment of Organization's Financial Standing to Integrated Methodology for Analysis of Sustainable Development. Digest Finance, 2017, vol. 22, iss. 2, pp. 123-143. Available at: https://doi.org/10.24891/df.22.2.123 
Figure 5

A scheme of complex analysis of organization's financial sustainability using the integrated index

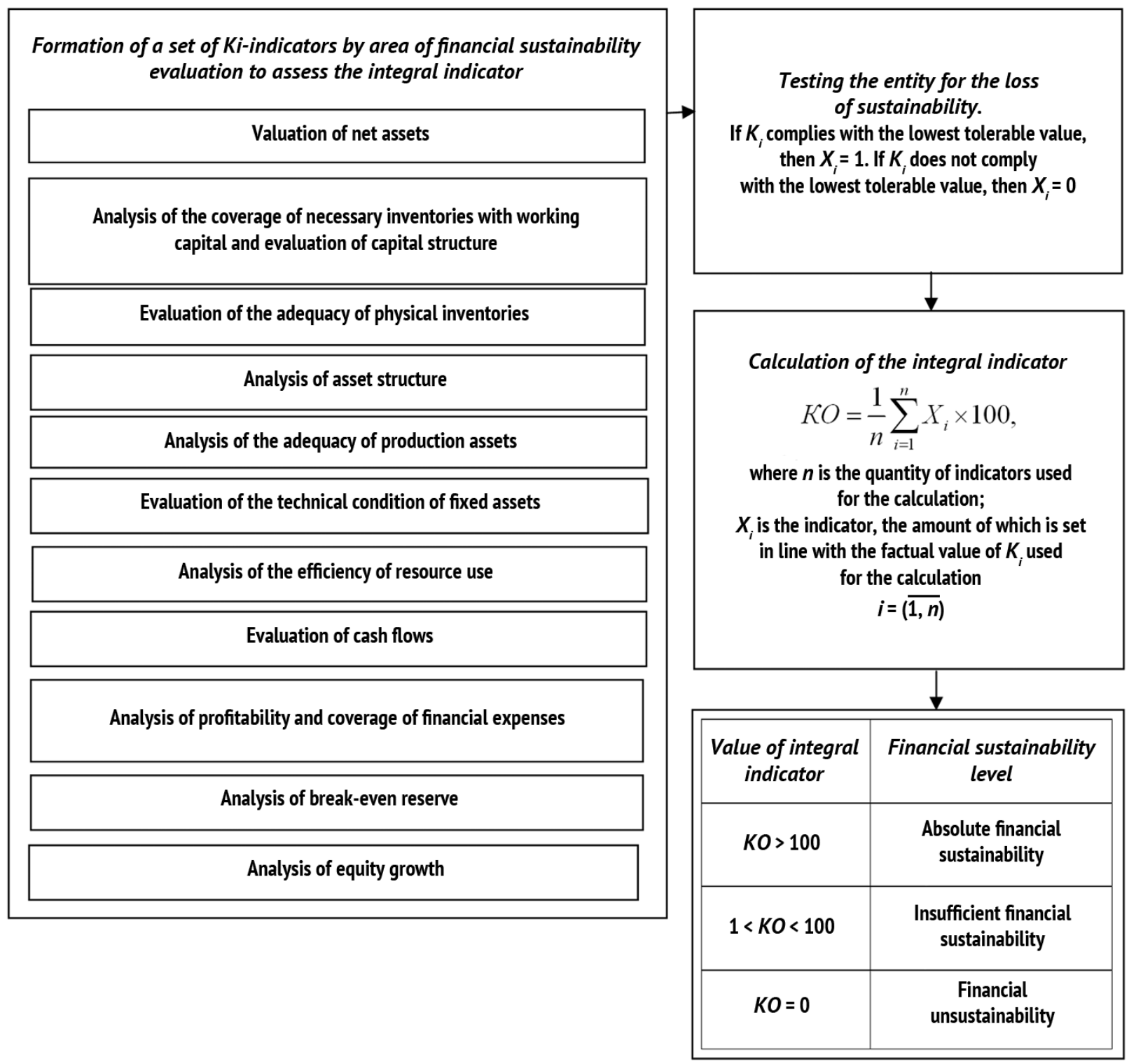

Source. Authoring, based on Bukhonova S.M., Doroshenko Yu.A., Benderskaya 0.B. [An integrated methodology to analyze the enterprise financial sustainability]. Ekonomicheskii analiz: teoriya i praktika = Economic Analysis: Theory and Practice, 2004, no. 7, pp. 8-15. (In Russ.) 


\section{Figure 6}

The study and identification of indicators characterizing the type of organization's development

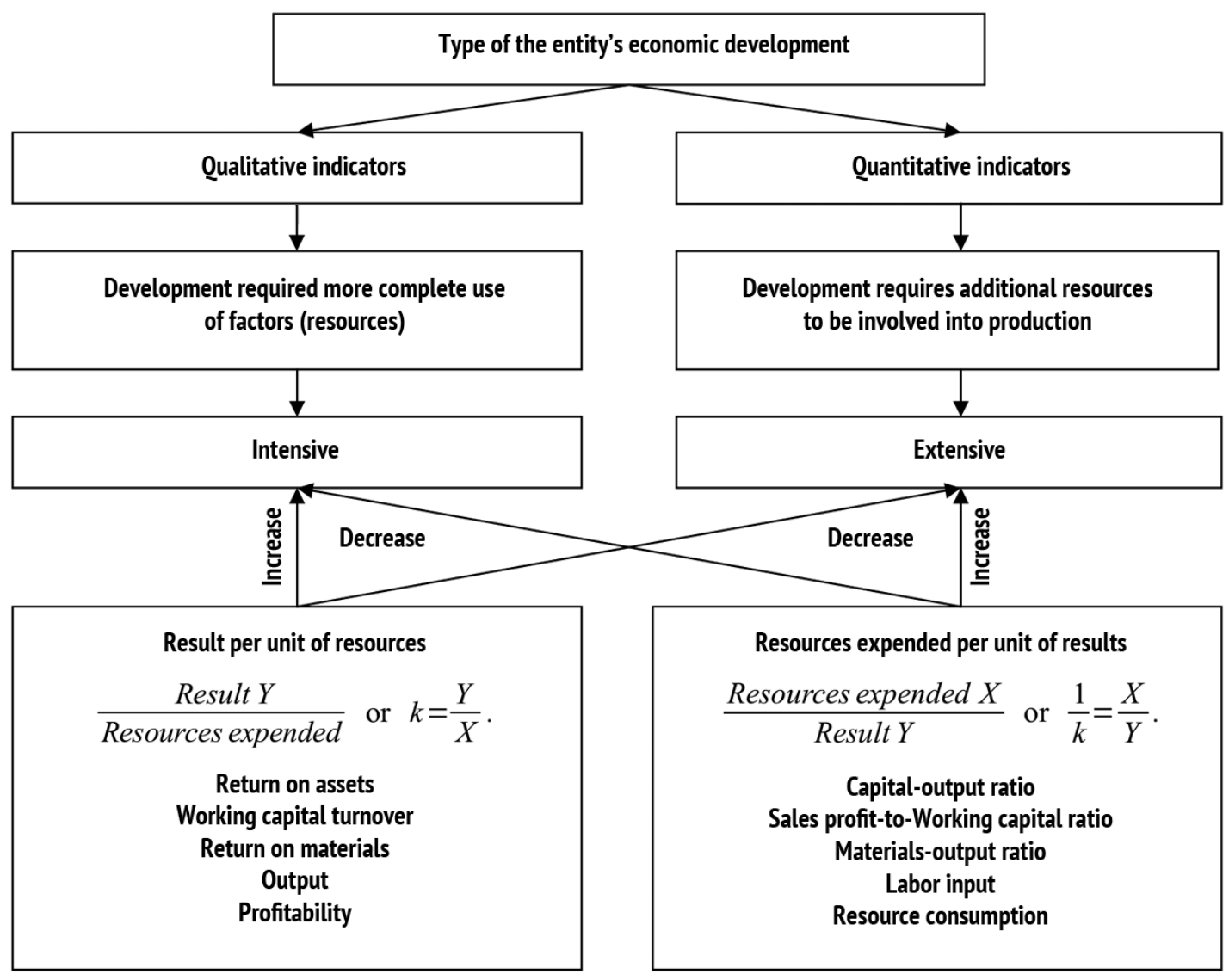

Source: Authoring 
Figure 7

A methodology for assessing the financial sustainability of the organization using the resource-based approach

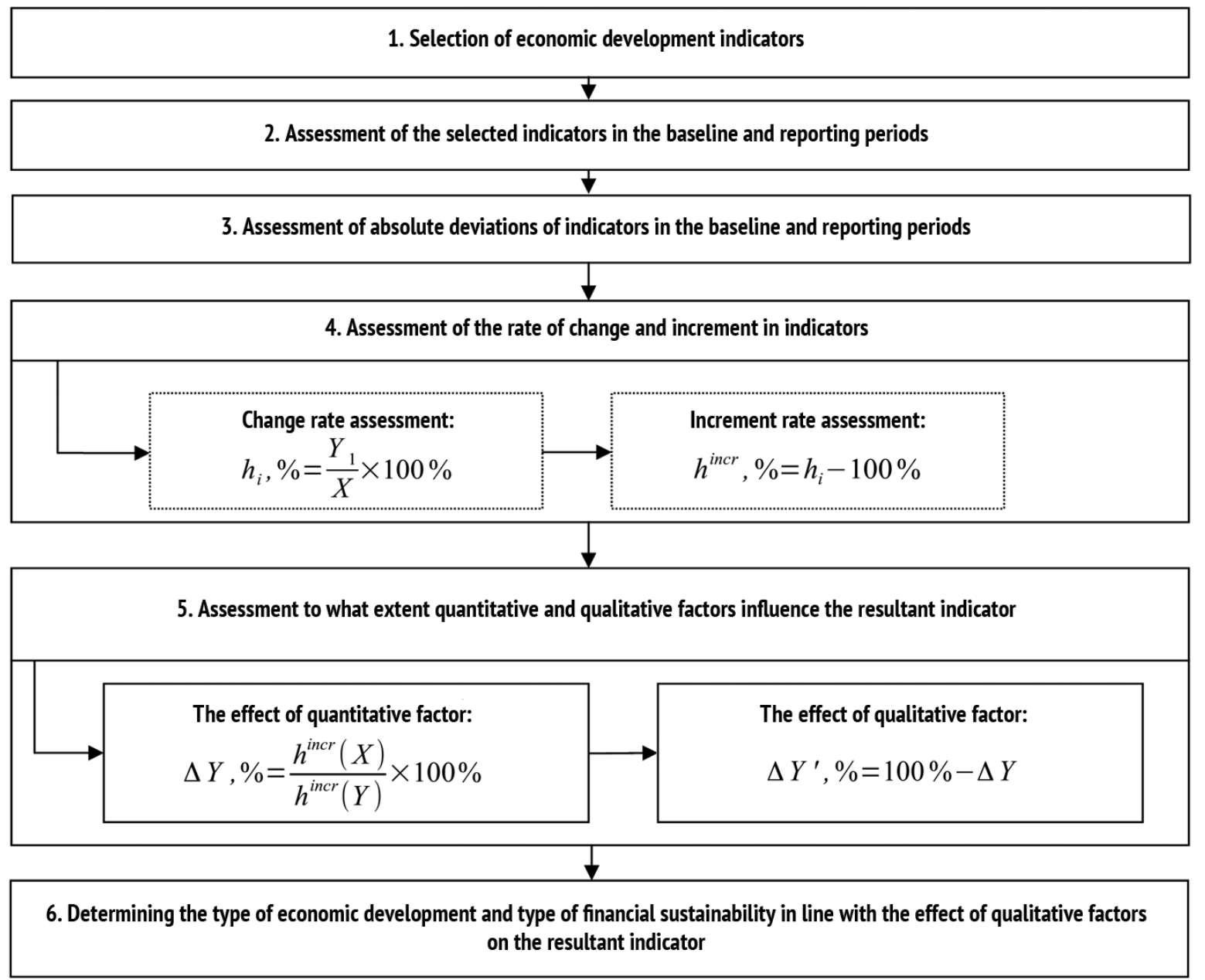

Source: Authoring

Please cite this article as: Endovitskii D.A., Lyubushin N.P., Babicheva N.E., Kupryushina 0.M. From Assessment of Organization's Financial 
Figure 8

Algorithm of integrated methodology to assess organization's sustainable development

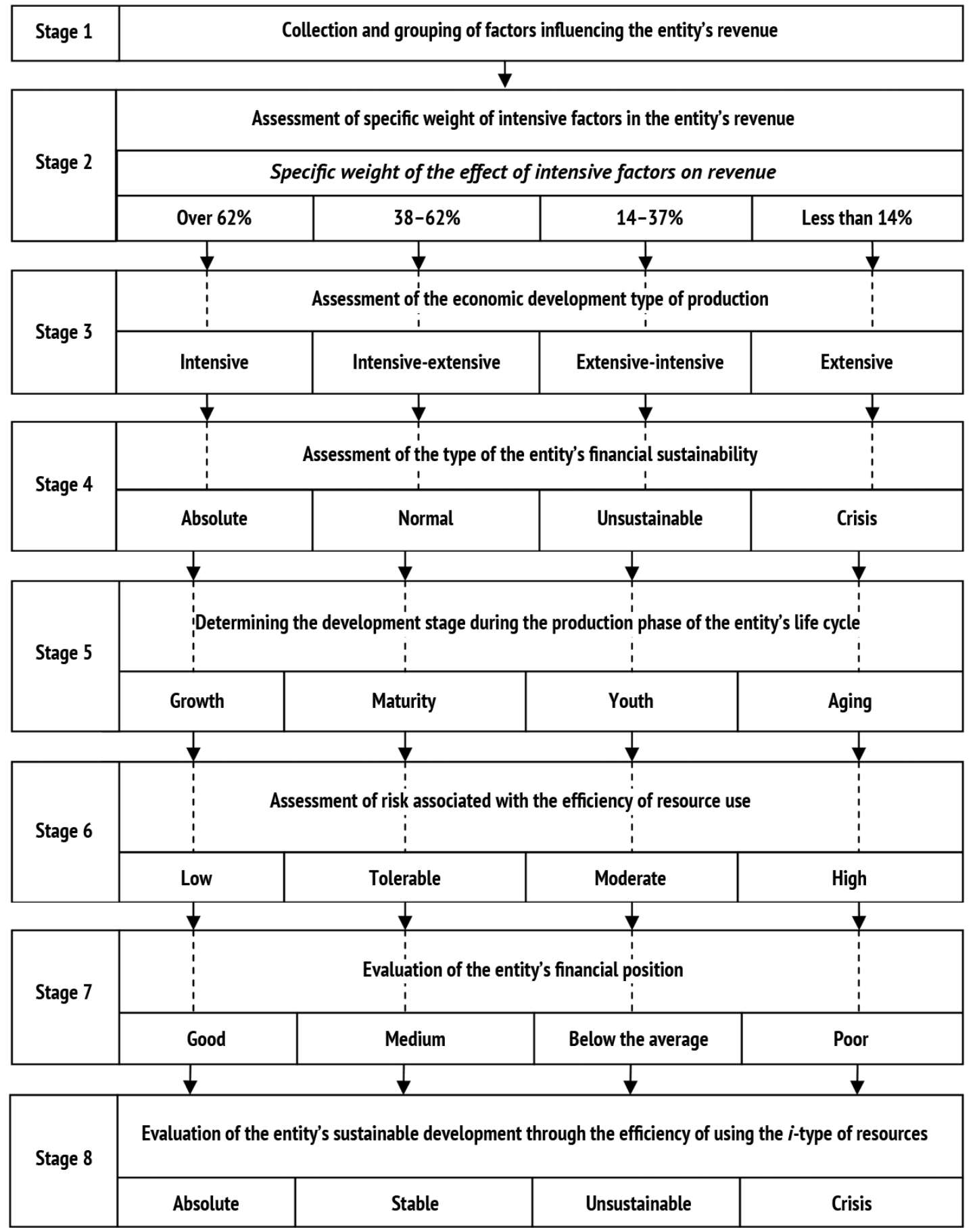

Source: Authoring

Please cite this article as: Endovitskii D.A., Lyubushin N.P., Babicheva N.E., Kupryushina 0.M. From Assessment of Organization's Financial Standing to Integrated Methodology for Analysis of Sustainable Development. Digest Finance, 2017, vol. 22, iss. 2, pp. 123-143. Available at: https://doi.org/10.24891/df.22.2.123 


\section{Acknowledgments}

This article was supported by the Russian Foundation for Basic Research, grant No. 15-06-06295.

The article was supported by the Publishing house FINANCE and CREDIT's Information center at the Voronezh State University.

\section{References}

1. Shershenevich G.F. Uchenie o nesostoyatel'nosti [The doctrine of insolvency]. Moscow, Kniga po trebovaniyu Publ., 2012, 472 p.

2. Zwißler F., Okhan E., Westkämper E. Lean and Proactive Liquidity Management for SMEs. Procedia CIRP, 2013, vol. 7, pp. 604-609. doi: 10.1016/j.procir.2013.06.040

3. Kovan S. [Analysis of financial condition and balance sheet structure of organizations on the basis of guidelines of the Federal Service of Russia for Financial Recovery and Bankruptcy]. Vestnik FSFO Rossii = Bulletin of Federal Service of Russia for Financial Recovery and Bankruptcy, 2001, no. 4, pp. 22-25. (In Russ.)

4. Endovitskii D.A., Babushkin V.A., Baturina N.A. et al. Analiz investitsionnoi privlekatel'nosti organizatsii [Analysis of investment appeal of the organization]. Moscow, KnoRus Publ., 2010, 376 p.

5. Gilyarovskaya L.T., Vekhoreva A.A. Analiz i otsenka finansovoi ustoichivosti kommercheskogo predpriyatiya [Analysis and assessment of financial soundness of commercial enterprises]. St. Petersburg, Piter Publ., 2003, $256 \mathrm{p}$.

6. Bernstein L.A. Analiz finansovoi otchetnosti [Financial Statement Analysis. Theory, Application, and Interpretation]. Moscow, Finansy i Statistika Publ., 2002, 621 p.

7. Kat'kalo V.S. [A resource-based concept of strategic management: Genesis of basic ideas and notions]. Vestnik Sankt-Peterburgskogo universiteta. Ser. 8: Menedzhment = Vestnik of Saint-Petersburg University. Series 8: Management, 2002, vol. 4, pp. 20-42. (In Russ.)

8. Kleiner G.B. [A resource-based theory of system organization of economy]. Rossiiskii zhurnal menedzhmenta= Russian Management Journal, 2011, vol. 9, no. 3, pp. 3-28. (In Russ.)

9. Penrose E., Pitelis C. The Theory of the Growth of the Firm. Oxford University Press, 2009, 304 p.

10. Wernerfelt B. A Resource-Based View of the Firm. Strategic Management Journal, 1984, vol. 5, no. 2, pp. 171-180. doi: $10.1002 /$ smj.4250050207

11. Rumelt R.P. Theory, Strategy, and Entrepreneurship. In: David Teece (ed.) The Competitive Challenge: Strategies for Industrial Innovation and Renewal. Cambridge, Mass., Ballinger Pub. Co., 1987, pp. 137-158.

12. Teece D.J., Pisano G., Shuen A. Firm Capabilities, Resources, and the Concept of Strategy: Four Paradigms of Strategic Management. U.C. Berkeley, Center for Research in Management. Consortium on Competitiveness and Cooperation Working Paper, 1990, vol. 90, no. 8, 64 p.

13. Barney J.B. Firm Resources and Sustained Competitive Advantage. Journal of Management, 1991, vol. 17, no. 1, pp. 99-120. doi: 10.1016/j.sbspro.2015.01.021

14. Peteraf M.A. The Cornerstones of Competitive Advantage: A Resource-Based View. Strategic Management Journal, 1993, vol. 14, no. 3, pp. 179-191. doi: 10.1002/smj.4250140303

15. Conner K.R., Prahalad C.K. A Resource-Based Theory of the Firm: Knowledge versus Opportunism. Organization Science, 1996, vol. 7, iss. 5, pp. 477-501. doi: http://dx.doi.org/10.1287/orsc.7.5.477

16. Kleiner G.B. [The State - Region - Industry - Enterprise: The frame of systemic stability of the Russian economy. Part 1]. Ekonomika regiona = Economy of Region, 2015, no. 2, pp. 50-58. (In Russ.) doi: 10.17059/2015-2-4 
17. Petukhov R.M. Otsenka effektivnosti promyshlennogo proizvodstva: metody i pokazateli [Evaluating the efficiency of industrial production: Methods and key figures]. Moscow, Ekonomika Publ., 1990, 95 p.

18. Prangishvili I.V. Sistemnyi podkhod i povyshenie effektivnosti upravleniya [Systems approach and improvement of management efficiency]. Moscow, Nauka Publ., 2005, 422 p.

19. Soroko E.M. Zolotye secheniya, protsessy samoorganizatsii i evolyutsii sistem: vedenie v obshchuyu teoriyu garmonii sistem [The Golden section, processes of self-organization and evolution of systems: Introduction to the general theory of system harmony]. Moscow, LIBROKOM Publ., 2012, 264 p.

20. Arnold V.I. Teoriya katastrof [Catastrophism]. Moscow, Nauka Publ., 1990, 128 p.

21. Zhirmunskii A.V., Kuz'min A.V. Kriticheskie urovni v razvitii prirodnykh sistem [Critical levels in the development of natural systems]. Leningrad, Nauka Publ., 1990, 223 p.

22. Bushuev V.V. Energeticheskii potentsial i ustoichivoe razvitie [Energy potential and sustainable development]. Moscow, Energiya Publ., 2006, 320 p.

23. Babicheva N.E. Teoretiko-metodologicheskie osnovy ekonomicheskogo analiza razvitiya organizatsii na osnove resursnogo podkhoda: monografiya [Theoretical and methodological framework for economic analysis of organizations' development based on the resource approach: a monograph]. Moscow, ID FINANSY i KREDIT Publ., 2012, 256 p.

24. Pecchei A. Chelovecheskie kachestva [Human Qualities]. Moscow, Progress Publ., 1985, 312 p.

25. Marfenin N.N. Rossiya v okruzhayushchem mire: 2002 [Russia in the outside world: 2002]. Moscow, IIUEPS Academy Publ., 2002, 336 p.

26. Danilov-Danil'yan V.I. [Sustainable development (a theoretical-methodological analysis)]. Ekonomika i matematicheskie metody = Economics and Mathematical Methods, 2003, vol. 39, no. 2, pp. 123-135. (In Russ.)

27. Uskova T.V. Upravlenie ustoichivym razvitiem regiona [Managing the sustainable development of the region]. Vologda, ISEDT RAS Publ., 2009, 355 p.

28. Cornescu V., Adam R. Considerations Regarding the Role of Indicators Used in the Analysis and Assessment of Sustainable Development in the E.U. Procedia Economics and Finance, 2014, vol. 8, pp. 10-16. doi: 10.1016/S2212-5671(14)00056-2

29. Dvořáková L., Zborková J. Integration of Sustainable Development at Enterprise Level. Procedia Engineering, 2014, vol. 69, pp. 686-695. doi: 10.1016/j.proeng.2014.03.043

\section{Conflict-of-interest notification}

We, the authors of this article, bindingly and explicitly declare of the partial and total lack of actual or potential conflict of interest with any other third party whatsoever, which may arise as a result of the publication of this article. This statement relates to the study, data collection and interpretation, writing and preparation of the article, and the decision to submit the manuscript for publication. 